\title{
Oxygen Radicals as Second Messengers for Expression of the Monocyte Chemoattractant Protein, JE/MCP-1, and the Monocyte Colony-stimulating Factor, CSF-1, in Response to Tumor Necrosis Factor- $\alpha$ and Immunoglobulin G Evidence for Involvement of Reduced Nicotinamide Adenine Dinucleotide Phosphate (NADPH)- dependent Oxidase
}

Joseph A. Satriano, Marc Shuldiner, Kazuhiko Hora, Yun Xing, Zihe Shan, and Detlef Schlondorff Department of Medicine, Albert Einstein College of Medicine, Bronx, New York 10461

\begin{abstract}
The potential involvement of reactive oxygen species in the expression of genes involved in immune response was examined in mesangial cells. Tumor necrosis factor (TNF- $\alpha$ ) and aggregated (aggr.) IgG increased mRNA levels for the monocyte chemoattactant protein, JE/MCP-1, and the colony-stimulating factor, CSF-1. Scavengers for free radicals such as di- and tetra-methylthiourea (DMTU and TMTU) attenuated the increase in mRNA levels in response to TNF- $\alpha$ and aggr. IgG. Generation of superoxide anion by xanthine oxidase and hypoxanthine increased mRNA levels of these genes, but exogenous $\mathrm{H}_{2} \mathrm{O}_{2}$ did not. Addition of NADPH to activate a membranebound NADPH-oxidase generated superoxide and caused a dose-dependent increase in mRNA levels and further enhanced the stimulation by TNF- $\alpha$ or aggr. IgG. An inhibitor of NADPH-dependent oxidase 4'-hydroxy-3'-methoxy-acetophenone attenuated the rise in mRNA levels in response to TNF- $\alpha$ and aggr. IgG. By nuclear run-on experiments TNF- $\alpha$, aggr. IgG and NADPH increased the transcription rates for JE/MCP-1 and CSF-1, effects inhibited by TMTU. We conclude that generation of reactive oxygen species, possibly by NADPH-dependent oxidase, are involved in the induction of the JE/MCP-1 and CSF-1 genes by TNF- $\alpha$ and IgG complexes. The concerted expression of leukocyte-directed cytokines represents a general response to tissue injury. (J. Clin. Invest. 1993. 92:1564-1571.) Key words: gene regulation • kidney $\cdot$ mesangial cell
\end{abstract}

\section{Introduction}

Cytokines play a major role in tissue injury and repair. These processes also involve the participation of monocyte-macrophages. Recently a number of monocyte-specific cytokines have been described and include the monocyte colony-stimulat-

Address reprint requests to Dr. Detlef Schlondorff, Ullmann Building, Room 617, Albert Einstein College of Medicine, 1300 Morris Park Avenue, Bronx, NY 10461.

Received for publication 8 September 1992 and in revised form 11 May 1993.

J. Clin. Invest.

(c) The American Society for Clinical Investigation, Inc.

0021-9738/93/09/1564/08 \$2.00

Volume 92, September 1993, 1564-1571 ing factor (CSF-1), ${ }^{1}$ and the monocyte chemoattractant protein (MCP-1) (1-4). MCP-1 was identified as the product of a gene belonging to the small, inducible cytokine family, known in the murine system as the JE gene (5-9). CSF-1 is a cytokine required for the proliferation, maturation, activation, and survival of monocytes $(1,10)$. Expression of the JE/MCP-1 and CSF-1 genes can be rapidly induced by a number of agents, including LPS, PDGF, TNF- $\alpha$, Il-1, and IFN- $\gamma(2,4,6,11-$ 21 ). We recently described that occupancy of $F c$ receptors by IgG aggregates resulted in rapid expression of mRNA for and secretion of JE/MCP-1 and CSF-1 in cultured mouse mesangial cells (22). Mesangial cells (MC) represent modified vascular smooth muscle cells that fulfill the function of specialized pericytes within the glomerulus of the kidney (23). MC also play a role in glomerular injury, where influx and activation of monocyte-macrophages is important and local generation of MCP-1 and CSF-1 could contribute to this phenomenon (22, 24, 25).

The cellular signaling mechanisms for induction of JE/ MCP-1 and CSF-1 remain to be fully defined. While we have described that CAMP suppresses both basal and stimulated expression of both CSF-1 and JE/MCP-1 (26), the second messenger systems for the upregulation of these genes remain unclear. Recently it has been proposed that oxygen radicals may serve as second messenger system for gene activation, especially for genes under the regulation of the transcription factor NF- $k$ B (27-29). The potential for generation of oxygen radicals by membrane-bound NADPH-dependent oxidase systems may be present in many cell types, among them $\operatorname{MC}(30,31)$. Both TNF- $\alpha$ and IgG complexes are known stimulators of reactive oxygen species generation in $\mathrm{MC}(32-34)$. We therefore examined whether generation of free radicals could represent a second messenger system for induction of JE/MCP-1 and CSF-1 in mouse MC. Our results show that addition of scavengers for free radicals can attenuate expression of mRNA levels for these genes under basal conditions and after stimulation with TNF- $\alpha$ or IgG aggregates. In contrast, exogenous NADPH enhances basal and stimulated mRNA levels for JE/

1. Abbreviations used in this paper: aggr., aggregated (IgG); CSF, colony-stimulating factor; DMTU, dimethyl-thiourea; HMAP, 4'-hydroxy-3'-methoxy-acetophenone; MC, mesangial cell; MCP, monocyte chemoattractant protein; NAC, $N$-acetyl-L-cysteine; PDTC, pyrrolidone-thiocarbamate; TES, $N$-Tris (hydroxymethyl) methyl-2aminoethanesulfonic acid, pH 7.4; TMTU, tetramethylthiourea. 
MCP-1 and CSF-1 effects attenuated by inhibition of NADPH-dependent oxidase. These changes in mRNA levels are at least in part due to altered transcriptional rates. Thus reactive oxygen species generation, in part NADPH-dependent, may represent a second messenger system for induction of JE/MCP-1 and CSF-1 expression not only in response to TNF- $\alpha$ but also to Fc receptor occupancy by IgG. These findings provide further evidence for the hypothesis that free oxygen radicals can serve as second messenger systems, findings that may be of significance for cytokine induction during tissue injury.

\section{Methods}

Materials. $\left[{ }^{32} \mathrm{P}\right] \mathrm{dCTP}$, was obtained from New England Nuclear, Boston, MA. RPMI 1640 medium, penicillin $(0.66 \mathrm{mg} / \mathrm{ml}) /$ streptomycin $(60 \mathrm{mg} / \mathrm{ml})$ solution, FCS, and Dulbecco's PBS were purchased from Flow Laboratories Inc., McLean, VA. Nu-Serum was from Collaborative Research Inc., Bedford, MA. Recombinant mouse TNF- $\alpha$, NADPH, NADP, and multiprime DNA labeling systems were purchased from Boehringer Mannheim, Indianapolis, IN. Mouse IgG (Cappel Organon Teknika Corp., West Chester, PA) was aggregated by heating to $63^{\circ} \mathrm{C}$ for $30 \mathrm{~min}$. Insoluble aggregates were removed by centrifugation at $11,000 \mathrm{~g}$ for $5 \mathrm{~min}$ and the supernate served as aggregated (aggr.) IgG (22). 4'-Hydroxy-3'-methoxy-acetophenone (HMAP) was purchased from Aldrich Chemical Co., Milwaukee, WI. All other chemicals were from Sigma Chemical Co., St. Louis, MO, unless otherwise specified. The CDNA probe for the murine CSF-1 was kindly provided by Dr. Martha Ladner of Chiron Corp., Emeryville, CA (35), that for JE/MCP-1 by Dr. J. Stiles (7).

Culture of mouse MC. Mouse MC transformed with nonreplicating, non-capsid forming SV-40 virus (strain Rh 911) were kindly provided by Dr. E. Neilson, University of Pennsylvania, Philadelphia. These cells have been characterized (36). In preliminary experiments we established that the responses of these transformed mouse MC to TNF- $\alpha$ and IgG in terms of expression of JE/MCP- 1 and CSF- 1 were comparable to primary cultures of mouse $\mathrm{MC}$, used in our previous experiments $(22,26)$. The mMC were maintained in DME medium with $1 \%$ Pen-Strep and $2.5 \%$ FCS with twice weekly feedings in a $95 \%$ air, $5 \% \mathrm{CO}_{2}$ atmosphere. Cells were passaged at weekly intervals by harvesting with $0.25 \%$ trypsin, $1 \mathrm{mM}$ EDTA solution.

Measurement of superoxide generation. For measurement of superoxide generation, MC were cultured in 96-well plates and superoxide generation was determined as described by Pick and Mizel (37). In brief, culture media were removed and replaced by Earle's balanced salt solution $(0.1 \mathrm{ml})$ containing ferrichrome $c(50 \mu \mathrm{M})$ with or without the experimental agents indicated in Results. Parallel wells received in addition superoxide dismutase $(300 \mathrm{U} / \mathrm{ml})$. Appropriate blanks, i.e., wells without cells but containing the buffer with or without experimental agents, were run for each assay. Absorbance was read at 550-nm wavelength in a Multiskan reader (Flow Laboratories) after 0, 15, and $30 \mathrm{~min}$ of incubation and, after subtraction of the respective blanks, were converted to superoxide generated as described (37).

Northern blots. Total RNA was extracted from cultured cells by the method of Chomczynski and Sacchi (38). Aliquots (20 $\mu \mathrm{g})$ of total RNA were treated with glyoxal/DMSO, electrophoresed in $1.0 \%$ agarose gel along with RNA size standards (GIBCO/BRL, Gaithersburg, $M D$ ), and then transferred to nylon filters (gene screen, New England Nuclear, Boston, MA) (39). The cDNA probes were used for hybridization after $\left[{ }^{32} \mathrm{P}\right]$ dCTP labeling by random oligonucleotide priming (40). The filters were washed to a final high stringency of $0.1 \times$ SSPE, $1.0 \%$ SDS for $2 \times 30 \mathrm{~min}$ at $65^{\circ} \mathrm{C}$. Autoradiography was performed with an intensifying screen at $-70^{\circ} \mathrm{C}$ for appropriate time periods. The size of the respective RNA was identified by comparison with the ethidium bromide-stained RNA standards.

Nuclear runoff transcription assay. Confluent $\mathrm{MC}\left(2 \times 10^{7}\right.$ cells per condition) were incubated with experimental agents at $37^{\circ} \mathrm{C}$ for $1 \mathrm{~h}$.
Cultures were then washed with ice-cold PBS and the nuclei prepared by lysis in $0.5 \%$ NP-40 lysis buffer (41). Nuclei were collected by centrifugation and stored in $50 \mathrm{mM}$ Tris, $\mathrm{pH} 8.3,40 \%$ glycerol, $5 \mathrm{mM}$ $\mathrm{MgCl}_{2}, 0.1 \mathrm{mM}$ EDTA at $-150^{\circ} \mathrm{C}$. Upon thawing, nuclei were resuspended and incubated in an equal volume of reaction buffer containing $300 \mathrm{mM} \mathrm{KCl}, 0.5 \mathrm{mM}$ each of ATP, GTP, and CTP, and $100 \mu \mathrm{Ci}$ $\left[\alpha-{ }^{32} \mathrm{P}\right]$ UTP $\left(760 \mathrm{Ci} / \mathrm{mmol}\right.$, New England Nuclear) at $30^{\circ} \mathrm{C}$ for 30 $\mathrm{min}$. The reaction was terminated by the addition of $600 \mu$ l of RNase free DNase I $(200 \mathrm{U} / \mathrm{ml})$, for $5 \mathrm{~min}$ at $30^{\circ} \mathrm{C}$, followed by $200 \mu \mathrm{l} \mathrm{SDS}$ / Tris buffer ( $5 \%$ SDS, $0.5 \mathrm{M}$ Tris-Cl, pH 7.4, 0.125 M EDTA) and $10 \mu \mathrm{l}$ at $20 \mathrm{mg} / \mathrm{ml}$ Proteinase $\mathrm{K}$ for $30 \mathrm{~min}$ at $42^{\circ} \mathrm{C}$. The samples were then extracted with phenol/chloroform/isoamyl alcohol (25:24:1) and precipitated on ice in $5 \% \mathrm{TCA} / 30 \mathrm{mM}$ sodium pyrophosphate solution. The precipitates were trapped on a Millipore-type HA $(0.45 \mu \mathrm{m})$ filter and treated with $200 \mathrm{U}$ RNase free DNase I (Boehringer Mannheim) at $37^{\circ} \mathrm{C}$ for $30 \mathrm{~min}$. The reaction was quenched with $45 \mu \mathrm{l}$ of EDTA $(0.5$ $\mathrm{M})$, and $68 \mu \mathrm{l}$ of $20 \% \mathrm{SDS}$, eluted from the filters at $65^{\circ} \mathrm{C}$ and digested with proteinase $\mathrm{K}(4.5 \mu \mathrm{l} ; 20 \mathrm{mg} / \mathrm{ml})$ for $30 \mathrm{~min}$. After a final phenol/ chloroform/isoamyl alcohol extraction, the RNA was denatured by $\mathrm{NaOH}(750 \mu \mathrm{l}, 1 \mathrm{M})$ on ice for $10 \mathrm{~min}$, then quenched by the addition of $1.5 \mathrm{ml}$ of $1 \mathrm{M}$ Hepes (free acid) and ethanol precipitated $(0.53 \mathrm{ml} 3$ $M$ sodium acetate $+14.5 \mathrm{ml} 100 \%$ ethanol) overnight at $-20^{\circ} \mathrm{C}$. The RNA was spun down at $10,000 \mathrm{~g}$ for $30 \mathrm{~min}$ and the pellet resuspended in $1 \mathrm{ml}$ of TES ( $N$-Tris [hydroxymethyl]methyl-2-aminoethanesulfonic acid), pH 7.4, solution ( $10 \mathrm{mM}$ TES, $10 \mathrm{mM}$ EDTA, $0.2 \%$ SDS). $5 \mu \mathrm{l}$ of each sample was counted and samples subsequently were diluted with TES to normalize intersample variations in radioactivity. $1 \mathrm{ml}$ of TES-NaCl ( $10 \mathrm{mM}$ TES, $10 \mathrm{mM}$ EDTA, $0.2 \%$ SDS, $0.6 \mathrm{M} \mathrm{NaCl}$ ) was added to $1 \mathrm{ml}$ of the above RNA sample/TES solution $\left(10^{7} \mathrm{cpm}\right)$ and placed into a 5 -ml plastic scintillation vial containing $5 \mu \mathrm{g}$ of denatured, linearized DNA immobilized on strips of gene-screen (DuPont/ NEN, Wilmington, DE) nylon membrane and allowed to hybridize for $36 \mathrm{~h}$ at $65^{\circ} \mathrm{C}(41)$.

After hybridization, the membranes were washed twice in $20 \mathrm{ml}$ of $2 \times \mathrm{SSC}$ for $1 \mathrm{~h}$ at $65^{\circ} \mathrm{C}$. Unhybridized RNA was then digested in $8 \mathrm{ml}$ of $2 \times$ SSC containing $8 \mu \mathrm{l}$ of $10 \mathrm{mg} / \mathrm{ml} \mathrm{RNase} A$ for $30 \mathrm{~min}$ at $37^{\circ} \mathrm{C}$. Increasingly stringent washes were performed as follows: once $2 \times$ SSC in $0.1 \% \mathrm{SDS}$ at $65^{\circ} \mathrm{C}$ for $30 \mathrm{~min}$, once $1 \times \mathrm{SSC}$ with $0.1 \% \mathrm{SDS}$ at $65^{\circ} \mathrm{C}$ for $30 \mathrm{~min}$, twice $0.1 \times \mathrm{SSC}$ with $0.1 \% \mathrm{SDS}$ at $65^{\circ} \mathrm{C}$ for $30 \mathrm{~min}$, twice $0.1 \times \mathrm{SSC}$ at room temperature for $30 \mathrm{~min}$. The filters were then blotted dry on Whatman Inc. (Clifton, NJ) $3 \mathrm{MM}$ paper, and exposed to X-ray film at $-70^{\circ} \mathrm{C}$ using intensifying screens.

\section{Results}

Radical scavengers decrease $m R N A$ levels for JE/MCP-1 and $C S F-1$ after stimulation with TNF- $\alpha$ or IgG. Previously we have shown that exposure of MC to TNF- $\alpha$ or aggr. IgG results in increased levels of mRNA for JE/MCP-1 and CSF-1 (22, 26 ). Both TNF- $\alpha$ and IgG complexes also enhance free oxygen radical formation by cultured $\mathrm{MC}(32-34)$. We therefore examined whether scavengers for free radicals such as dimethyl and tetra-methylthiourea (DMTU and TMTU) (42) could influence mRNA levels. As shown in Fig. 1, both DMTU and TMTU decreased mRNA levels for CSF- 1 and JE/MCP-1 in response to either TNF- $\alpha$ or aggr. IgG. Equimolar urea, used as a nonscavenger control, had no effect. TMTU also suppressed the induction by cycloheximide (Fig. 1). Neither DMTU or TMTU influenced expression of GAPDH, a housekeeping gene, indicating that these agents did not suppress mRNA expression nonspecifically.

Reduced gentathione and glutathione peroxidase represent a major intracellular defense system against oxygen-derived free radicals (43). Addition of $N$-acetylcysteine (NAC) to cells increases intracellular glutathione levels (44). We have reported that NAC ( $10 \mathrm{mM})$ increased glutathione content of 


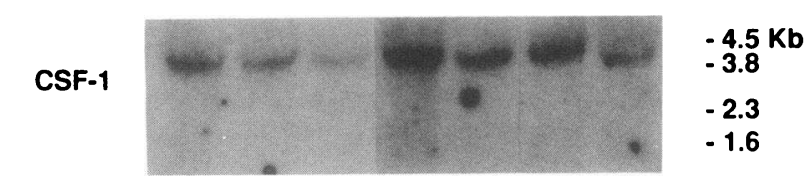

JE/MCP-1

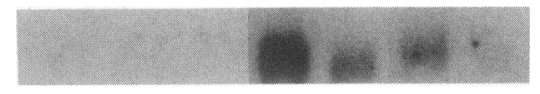

$-0.8$

GAPDH

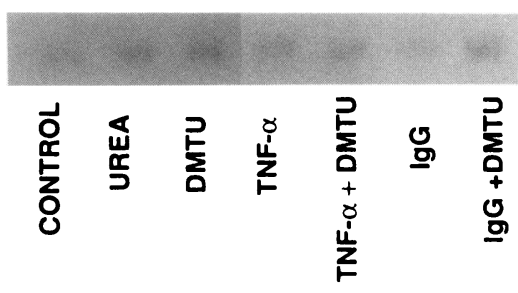

CSF-1

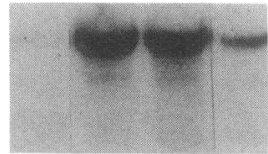

JE/MCP-1

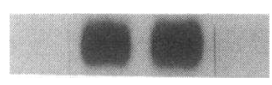

GAPDH
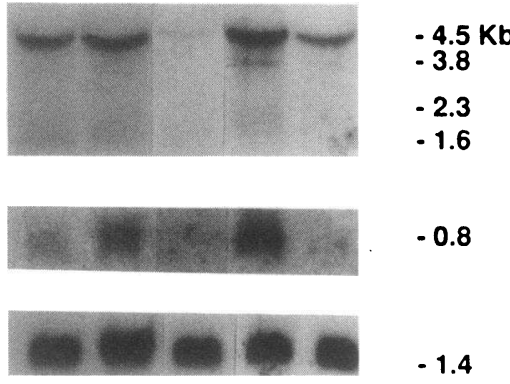

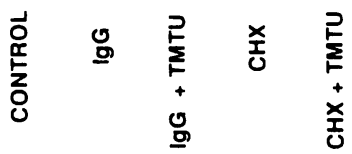

Figure 1. Northern blot analysis for mRNA levels of CSF-1, JE/MCP-1, and GAPDH. Mesangial cells were incubated for $4 \mathrm{~h}$ before RNA extraction under control conditions or in the presence of TNF- $\alpha\left(100 \mathrm{U} / \mathrm{ml}\right.$ or $\left.1.7 \times 10^{-10} \mathrm{M}\right)$, aggregated $\mathrm{IgG}(200 \mu \mathrm{g} / \mathrm{ml})$, cycloheximide $(C H X ; 15 \mu \mathrm{g} / \mathrm{ml})$, urea $(10 \mathrm{mM})$, dimethylthioruea $(D M T U ; 10 \mathrm{mM})$, tetramethylthiourea (TMTU; $10 \mathrm{mM}$ ) or combinations thereof. Position of RNA size markers are indicated in kilobases on the right. Results are from representative experiments and were confirmed in two to four experimental sets each.
MC by $40 \%$ from $89 \pm 6 \mathrm{nmol} / \mathrm{mg}$ protein to $137 \pm 20$ (45). Addition of NAC consistently blunted the increase in mRNA for JE/MCP-1 and CSF-1 in response to TNF- $\alpha$ (Fig. $2 A$ ). In contrast, NAC did not decrease mRNA levels in response to aggr. IgG (Fig. $2 A$ ).

Another thiol compound and radical scavenger, pyrrolidone-dithio-carbamate (PDTC) has been shown to inhibit the TNF- $\alpha$-induced activation of the transcription factor NF- $\kappa$ B in several cell lines (27-29). In MC, addition of PDTC (0.1 mM) reduced mRNA levels for JE/MCP-1 in response to TNF- $\alpha$ and IgG (Fig. $2 \mathrm{~B}$ ). However at the concentration of $0.1 \mathrm{mM}$ PDTC did not decrease mRNA levels for CSF-1 in response to either TNF- $\alpha$ or IgG (Fig. 2 B). Even at $1 \mathrm{mM}$ PDTC did not influence mRNA levels for CSF-1 (results not shown). Thus regulation of the CSF-1 gene appears to differ in respect to susceptibility to PDTC inhibition.

Generation of superoxide does, but $\mathrm{H}_{2} \mathrm{O}_{2}$ does not increase $m R N A$ levels for JE/MCP-1 and CSF-1. Taken together, these results show that scavengers of free radicals can attenuate the expression of JE/MCP-1 and CSF-1 in response to TNF- $\alpha$ and aggr. IgG, which could indicate that free radicals are involved in the intracellular signaling. We therefore examined whether exogenous reactive oxygen species could also enhance mRNA levels for these genes. Direct addition of 50 or $100 \mu \mathrm{M} \mathrm{H}_{2} \mathrm{O}_{2}$ to

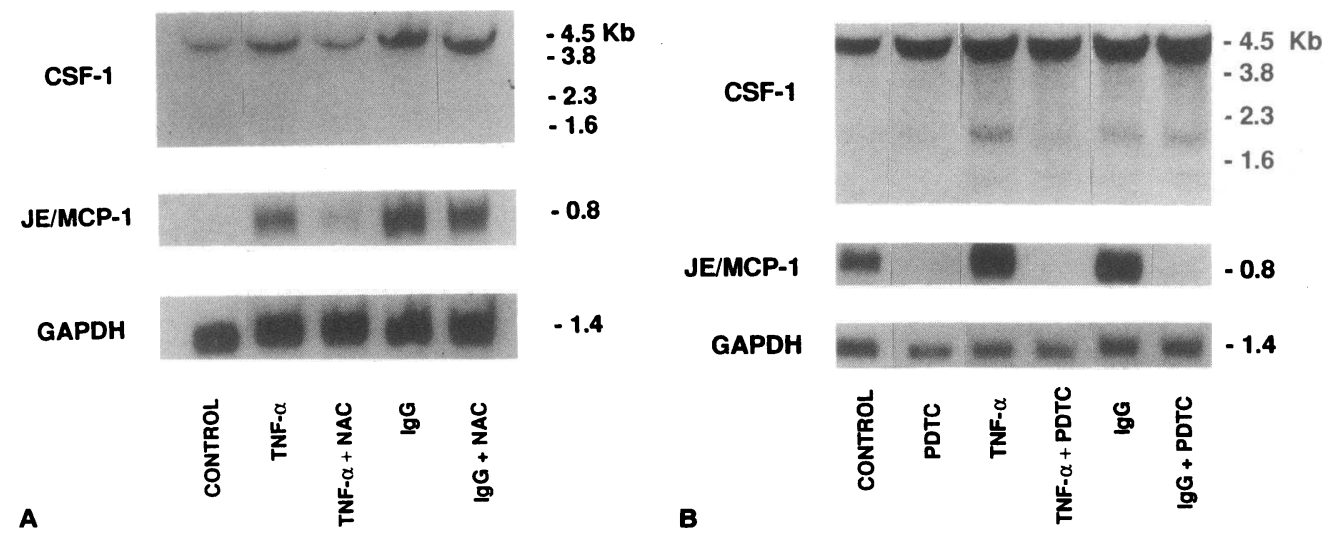

Figure 2. Effects of $(A) N$-acetylcysteine $(N A C ; 10 \mathrm{mM})$ or $(B)$ pyrrolidone-dithio-carbamate $(P D T C ; 0.1 \mathrm{mM})$ on mRNA levels for CSF-1, JE/ MCP-1, or GAPDH in mesangial cells incubated for $4 \mathrm{~h}$ with TNF- $\alpha(100 \mathrm{U} / \mathrm{ml})$ or aggregated IgG $(200 \mu \mathrm{g} / \mathrm{ml})$. 


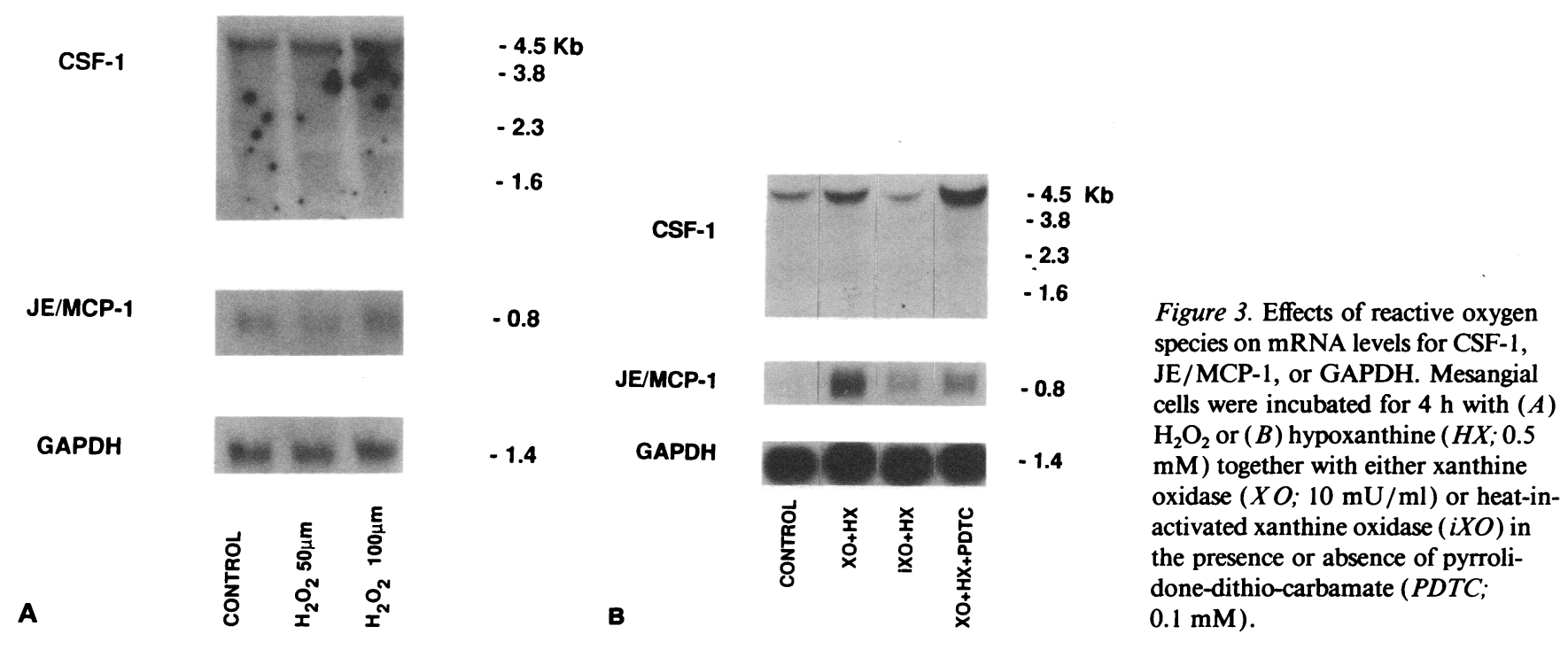

MC had no effect on mRNA levels (Fig. $3 A$ ). In contrast generation of superoxide by the addition of xanthine oxidase and hypoxantine increased mRNA levels for JE/MCP-1 and CSF-1 (Fig. $3 \mathrm{~B}$ ). Heat-inactivation of xanthine oxidase attenuated this response. PDTC decreased the increase in mRNA for JE/MCP-1 but not CSF-1 in response to xanthine-oxidasehypoxanthine (Fig. $3 B$ ), comparable to PDTC's effect on the TNF- $\alpha$ and aggr. IgG response (Fig. $2 B$ ).

NADPH increases $m R N A$ levels for JE/MCP-1 and CSF-1 effects attenuated by radical scavengers and an inhibitor of NADPH-dependent oxidase. The generation of oxygen free radicals by $\mathrm{MC}$ has been linked to a membrane-bound NADPHdependent oxidase system (31). This system could be stimulated by addition of NADPH to the extracellular medium (31), findings confirmed by us (Table I). We therefore examined the effect of increasing concentrations of NADPH in the medium on mRNA levels. As shown in Fig. $4 A$, addition of NADPH resulted in a dose-dependent increase of mRNA for JE/MCP-1 and CSF-1. The effect of NADPH was maximal at $5 \mathrm{mM}$ and showed a decline at $10 \mathrm{mM}$. The reasons for the decline at 10 $\mathrm{mM}$ is unclear at present. NADPH ( $5 \mathrm{mM})$ not only increased mRNA levels under basal conditions, but also after stimulation with TNF- $\alpha$ or aggr. IgG (Fig. $4 B$ ). Consistent with NADPH acting via enhancement of free radical formation, the radical scavengers DMTU and TMTU prevented the rise in mRNA

levels in the presence of NADPH (Fig. $4 C$ ). NADP, which is not a substrate for the NADPH-dependent oxidase, had no effect on the mRNA levels. These results are consistent with the proposal that free radical generation by a membranebound NADPH-dependent oxidase system contributes as a second messenger system to the induction of mRNA for JE/ MCP-1 and CSF-1. To further examine this hypothesis we used HMAP, an agent reported to be an inhibitor of the NADPH-dependent oxidase (46). In order to verify that MC generated superoxide under our experimental conditions we determined superoxide production. As shown in Table I, NADPH increased superoxide production under basal conditions and after stimulation by TNF- $\alpha$ or aggr. IgG, consistent with published reports (32-34). HMAP inhibited stimulation of superoxide generation. HMAP also decreased mRNA levels for JE/MCP-1 and CSF-1 during incubation of MC with TNF$\alpha$ or aggr. IgG (Fig. $4 D$ ), further supporting a mediator role for superoxide anion generated by NADPH-dependent oxidase in the activation of these genes.

$N A D P H, T N F-\alpha$, and IgG enhance transcription of $J E /$ $M C P-1$ and CSF-1, effects blocked by the radical scavenger TMTU. Levels of mRNA for both JE/MCP-1 and CSF-1 are regulated by transcriptional and post transcriptional mechanisms $(2,6,11-20)$. We used nuclear run-off assay technique to examine the transcriptional rates after incubation of MC

Table I. Generation of Superoxide by MC

\begin{tabular}{|c|c|c|c|c|c|c|}
\hline & Basal & HMAP & TNF- $\alpha$ & TNF- $\alpha+$ HMAP & $\lg G$ & IgG + HMAP \\
\hline & \multicolumn{6}{|c|}{ nmol/10 $10^{6}$ cells } \\
\hline -NADPH & & & & & & \\
\hline $\begin{aligned} & 30 \text { min incubation } \\
+ & \mathrm{NADPH}\end{aligned}$ & $7.3 \pm 0.6$ & $6.0 \pm 0.4$ & $14.3 \pm 1.6^{*}$ & $8.9 \pm 1.6$ & $18.4 \pm 2.8^{*}$ & $9.2 \pm 1.3$ \\
\hline 15 min incubation & $11.1 \pm 0.6$ & $6.9 \pm 1.2$ & $21.6 \pm 2.5^{*}$ & $7.6 \pm 0.9$ & $27.9 \pm 2.2^{*}$ & $13.0 \pm 1.5$ \\
\hline
\end{tabular}

MC were incubated with the experimental agents and superoxide generation was determined as described in Methods. Analysis of variance was performed using the Fisher PLSD and Scheffe- $F$ test to evaluate differences between groups. Results are means \pm SEM of six to eight series of incubations for each condition. Because of the lower rates of $\mathrm{O}_{2}$ generation, incubations were performed for 30 min in the absence of NADPH. In the presence of NADPH $(5 \mathrm{mM})$ generation of superoxide tended to level off after $20 \mathrm{~min}$ and incubations + NADPH were therefore carried out for 15 min only. * $P<0.05$ as compared to respective basal values by either test. 


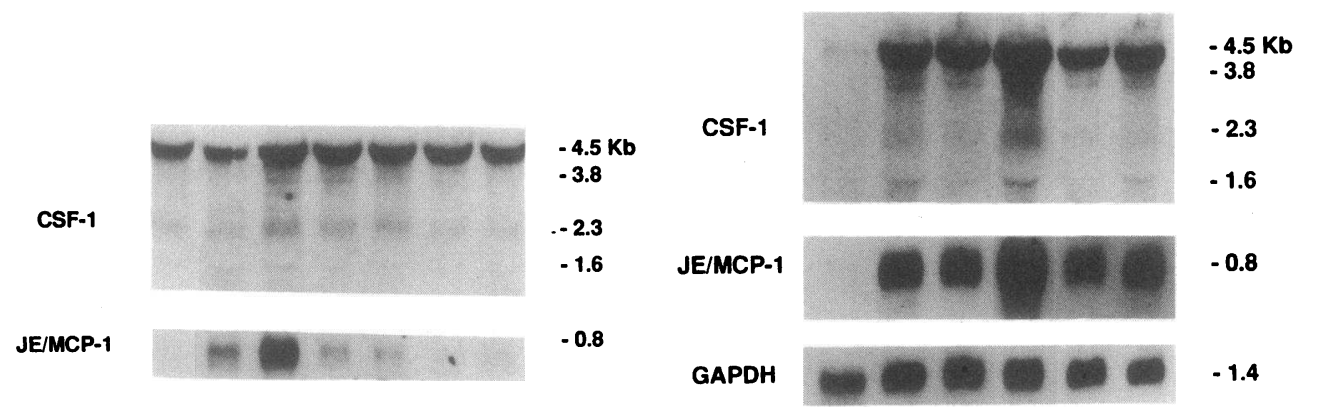

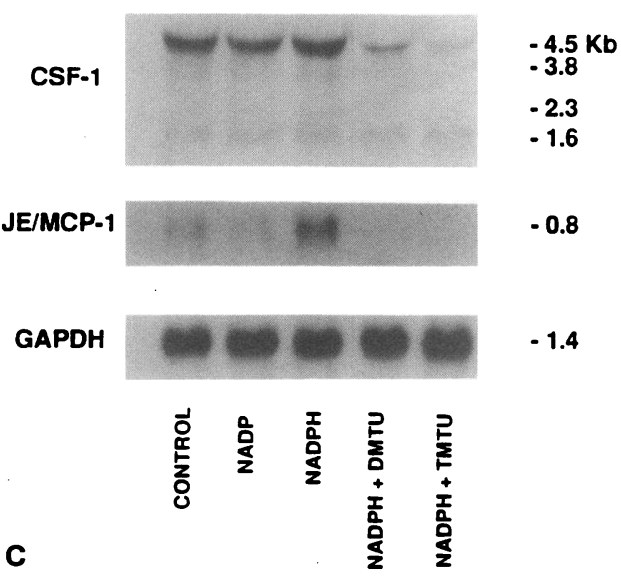

B

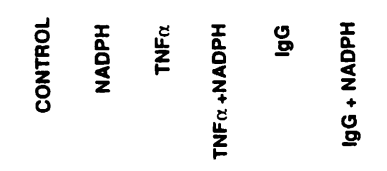

CSF-1

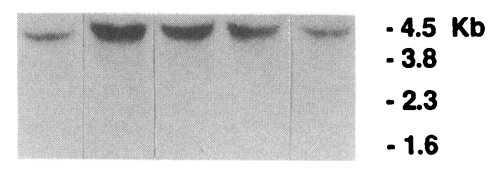

JE/MCP-1

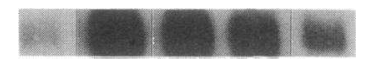

$-0.8$

GAPDH

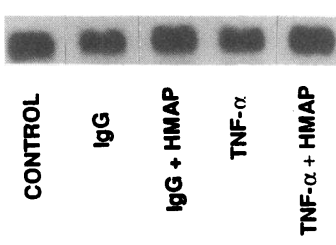

Figure 4. $(A)$ Effects of addition of increasing concentrations of NADPH (from 0 to $10 \mathrm{mM}$ ) to the incubation medium on mRNA levels for CSF-1, JE/MCP-1, and GAPDH extracted from mesangial cells after $4 \mathrm{~h}$ of incubation. (B) NADPH ( $5 \mathrm{mM})$ alone or in combination with TNF- $\alpha$ ( $100 \mathrm{U} /$ $\mathrm{ml})$ or aggregated IgG ( $200 \mu \mathrm{g}$ / $\mathrm{ml}$ ) on RNA levels of CSF-1, JE/ MCP-1, or GAPDH. ( $C$ ) Comparison of the effects of NADP ( 5 $\mathrm{mM}$ ) or NADPH ( $5 \mathrm{mM}$ ) alone or in combination with DMTU or TMTU ( $10 \mathrm{mM}$ ) on mRNA levels. (D) Effects of NADPH (5 $\mathrm{mM}$ ) and/or hydroxy-methoxyacetophenone (HMAP; $100 \mu \mathrm{g}$ / $\mathrm{ml}$ ) in combination with TNF- $\alpha$ $(100 \mathrm{U} / \mathrm{ml})$ or aggregated IgG $(200 \mu \mathrm{g} / \mathrm{ml})$ on mRNA levels. with NADPH, TNF- $\alpha$ or aggr. IgG in the presence and absence of the radical scavenger TMTU. TNF- $\alpha$ and IgG both increased transcription for JE/MCP-1 and CSF-1 (Fig. 5). Pretreatment of the cells with $5 \mathrm{mM}$ NADPH also resulted in enhanced transcriptional activity for both genes (Fig. 5). TMTU decreased basal transcriptional activity for JE/MCP-1 and CSF- 1 and attenuated the increase in response to NADPH,

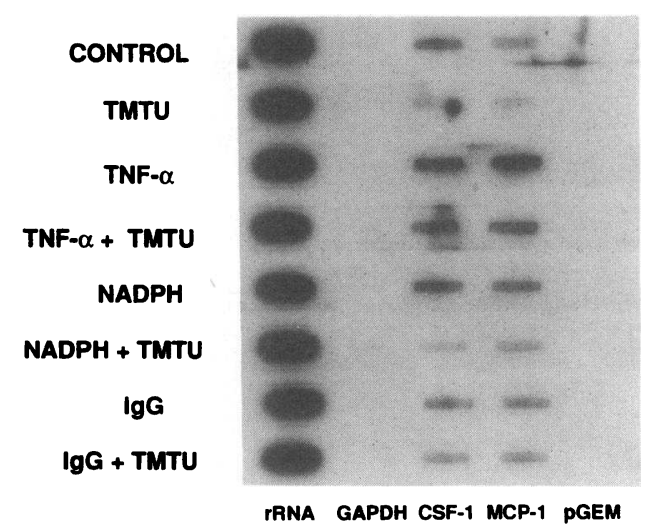

Figure 5. Nuclear run-off analysis for transcriptional activity in nuclei isolated from mesangial cells after $1 \mathrm{~h}$ of incubation under the conditions indicated. Labeled transcripts $\left(10^{7} \mathrm{cpm}\right)$ generated by the nuclei were hybridized with cDNA for either ribosomal RNA (as a nonspecific, positive control), GAPDH, CSF-1, JE/MCP-1, or the plasmid vector $\mathrm{pGEM}-4 \mathrm{Z}$ (as a negative control).
TNF- $\alpha$ or aggr. IgG (Fig. 5). These results are consistent with changes in transcriptional activity contributing to the observed changes in mRNA levels. None of the experimental agents had an affect on transcription for ribosomal RNA or GAPDH.

\section{Discussion}

Our results show that scavengers of free radicals can suppress the expression of the JE/MCP-1 and CSF-1 genes in response to TNF- $\alpha$ or aggr. IgG in MC, whereas addition of exogenous NADPH increased their expression under basal and stimulated conditions. The stimulation of the gene expression is also attenuated by radical scavengers. Furthermore, a putative inhibitor of NADPH-dependent oxidase also attenuates the increase in mRNA for CSF-1 and JE/MCP-1 in response to aggr. IgG or TNF- $\alpha$. We therefore conclude that free radicals generated-at least in part-by an NADPH-dependent oxidase system can serve as second messengers for activation of the JE/MCP-1 and CSF-1 genes in response to TNF- $\alpha$ and aggr. IgG. Thus generation of reactive oxygen species in response to occupancy of Fc receptor by aggr. IgG and TNF- $\alpha$ receptor occupancy does not only result in the oxygen burst, but may also serve as a signaling system for cytokine generation. The concerted expression of the leukocyte chemoattractant and activating cytokines MCP-1 and CSF-1 may regulate leukocyte influx to sites of tissue injury.

Recently it has been proposed that free radicals may serve as intracellular signals for gene activation involving specific 
transcription factors such as NF- $\kappa \mathrm{B}(27-29,44)$. This hypothesis is supported by data showing that the activation of NF- $\kappa$ B by, e.g., TNF- $\alpha$ is blunted by NAC and PDTC $(27,28,44)$. NAC increases the intracellular glutathione content which serves as a major protectant against free radicals (43). The thiol-containing PDTC also serves as a radical scavenger (27). Trans-activation by the phorbol responsive transcription factor AP-1 could also be induced by oxygen radicals, but was not blocked by NAC (27). The mechanism(s) of the free radical generation may involve a membrane-bound NADPH-dependent oxidase that appears to be present in many cell types (30). Furthermore, a membrane-bound NADPH-oxidase system was described in MC and addition of exogenous NADPH enhanced superoxide generation in response to stimuli (31). Generation of superoxide in response to, e.g., TNF- $\alpha$ and IgG complexes has also been reported for $\mathrm{MC}(32,34)$, results confirmed in our present studies with mouse MC. Furthermore, our studies show that HMAP, a putative inhibitor of the NADPH-dependent oxidase system (46), also inhibits superoxide generation in MC under basal conditions and after stimulation with NADPH, TNF- $\alpha$, or aggr. IgG. These changes in superoxide generation are associated with parallel changes in mRNA levels for inducible cytokines. For example, exogenous NADPH, but not NADP, increases mRNA levels for JE/ MCP1 and CSF- 1 under basal conditions and in response to TNF- $\alpha$ or aggr. IgG. In both our study and that of Radeke et al. (31), extracellular addition of NADPH increased superoxide production, especially in the presence of IgG or TNF- $\alpha$. Thus it has to be considered that exogenous NADPH may gain access to the cell membrane-bound oxidase system. A mediator role for NADPH-dependent superoxide generation in the altered gene expression is further supported by the data with HMAP. HMAP has been reported to inhibit NADPH-dependent oxidase and to suppress endothelial leukocyte adhesion molecule1 (ELAM-1) mRNA expression in endothelial cells (46). In our studies suppression of superoxide generation by HMAP also resulted in an attenuation of the rise in mRNA levels for CSF- 1 and JE/MCP-1 in response to NADPH with TNF- $\alpha$ or aggr. IgG. Thus generation of oxygen radicals and levels of mRNA for these genes change in a concordant manner under the experimental conditions used. The fact that the NADPHdependent responses could be abrogated by addition of cellpermeable free radical scavengers, such as PDTC, DMTU, and TMTU, but not by the nonscavenger urea is consistent with the NADPH effect being mediated by free radical generation. The free radical involved may represent superoxide anion, inasmuch as generation of superoxide by addition of xanthine oxidase and hypoxanthine also increased the mRNA level, effects inhibitable by PDTC. In contrast, exogenous $\mathrm{H}_{2} \mathrm{O}_{2}$ had no effect on mRNA levels. These results are not necessarily at odds with those of Schreck et al. (27), who reported activation of NF- $\kappa$ B by extracellular $\mathrm{H}_{2} \mathrm{O}_{2}$. These authors noted that $\mathrm{H}_{2} \mathrm{O}_{2}$ may not have had a direct effect but probably involved an additional cellular reaction induced by $\mathrm{H}_{2} \mathrm{O}_{2}$.

Reduced glutathione together with the glutathione peroxidase represent the major intracellular defense system against oxidant stress (43). Addition of NAC can increase the intracellular glutathione levels and thereby enhance the radical scavenging potential of cells $(27,44)$. Previous studies had reported that NAC as well as the radical scavenger PDTC are able to reduce the activation of NF- $\kappa \mathrm{B}$ in response to TNF- $\alpha$ (27, 44). Consistent with these reports and our results with the scav- engers TMTU and DMTU, addition of NAC and PDTC also diminished the increase in mRNA for JE/MCP-1 in response to TNF- $\alpha$. However, PDTC did not alter mRNA levels for CSF-1, in spite of inhibition by TMTU and DMTU. This may indicate that CSF-1 expression is regulated in a different manner than JE/MCP-1. Results with NAC were also divergent. NAC did not reduce the mRNA response of CSF-1 to aggr. IgG but suppressed that in response to TNF- $\alpha$. This would indicate that the intracellular signaling in response to TNF- $\alpha$ or to aggr. IgG involves, at least in part, different pathways. We speculate that the effect of aggr. IgG via Fc receptors on gene activation may involve several signaling systems and transcription factors, that are differentially influenced by NAC. For example, the AP-1 transcription factors require reduced glutathione in order to effectively bind to and initiate DNA transcription (47), and phorbol ester activation of AP-1 was not inhibited by NAC in the studies of Schreck et al. (27). IgG receptor occupancy results in both generation of oxygen radicals and activation of protein kinase $C$ pathway $(34,48)$, while the effect of TNF- $\alpha$ on gene activation appears to be kinase $C$ independent (49). Thus, in response to aggr. IgG, NAC will decrease the free radical pathway but have no effect or may even increase the protein kinase $\mathrm{C}$ and AP-1 pathway. This could explain the absence of an inhibitory effect of NAC on mRNA levels in response to $\mathrm{IgG}$. In the case of signaling via free radicals without contribution by kinase C, as might apply to TNF- $\alpha$, NAC would markedly reduce the mRNA response, as was indeed observed. It is clear that additional experiments will be required to address these issues.

The mechanism for the increase in mRNA levels for JE/ MCP-1 and CSF- 1 in response to TNF- $\alpha$, aggr. IgG, and NADPH involves enhanced transcription as demonstrated by the nuclear run-on experiments. The run-on experiments also show that the decreases in $\mathrm{mRNA}$ for JE/MCP- 1 and CSF- 1 in the presence of the radical scavenger TMTU are primarily due to lower transcriptional activity. However, both the JE/MCP-1 and CSF-1 gene contain AUUUA rich sequences in their $3^{\prime}$ untranslated regions that have been associated with instability of mRNA (50). Thus the possibility of additional post-transcriptional regulation of these mRNA species has to be considered. Our present experiments did not address this possibility. However the down-regulation of mRNA levels by radical scavengers does not require de novo protein synthesis as it was also observed in the presence of cycloheximide, which superinduces both the CSF-1 and JE/MCP-1 genes $(11,16)$. This finding is consistent with the observation by Schreck et al. (27), who noted that NAC also decreased the effect of cycloheximide to activate NF- $\kappa$ B.

Free radicals could influence transcription by activation of transcription factors. For example, activation of NF- $\kappa \mathrm{B}$ has been shown to occur in response to a number of stimuli, including free radicals, TNF- $\alpha$, and cycloheximide and results in the inducible expression of a number of genes (51). Both the murine CSF-1 and the human MCP-1 gene contain NF- $\kappa$ B binding sites $(18,52)$. Furthermore, it has been proposed that NF- $\kappa \mathrm{B}$ may act as a signal for cell distress in response to many adverse conditions (51). Activation of NF- $\kappa$ B would coordinate the generation of numerous products, including cytokines and intercellular adhesion molecules, that are important for tissue defense, remodeling, and inflammation (29, 51). Generation of MCP-1 would certainly fit into this overall picture. The fact that cytokines can be regulated by free radical genera- 
tion is of particular interest as hypoxia-reperfusion and inflammatory injury are associated with increased generation of free radicals. Local generation of oxygen radicals could represent a factor responsible for the expression of JE/MCP-1 in ischemic renal injury, reported by Safirstein et al. (53), and in immunemediated in vivo $\mathrm{MC}$ glomerulonephritis $(25,54)$. In the case of glomerular immune injury, triggers for reactive oxygen species generation could include TNF- $\alpha$ (32), immune complexes (22), and complement (55). While generation of large amounts of free oxygen radicals may play a major role in tissue injury, regulated generation of low concentrations of oxygen radicals, possibly by NADPH-oxidase, may represent a second messenger system for generation of cytokines involved in tissue injury and repair in general.

\section{Acknowledgment}

This work was supported by grant DK-22036 from the National Institutes of Health.

\section{References}

1. Stanley, E. R., L. J. Guilbert, R. J. Tushinksi, and S. H. Bartelmez. 1983. CSF-1: a mononuclear phagocyte lineage-specific hemopoietic growth factor. $J$. Cell. Biochem. 21:151-159.

2. Leonard, E. J., and T. Yoshimura. 1990. Human monocyte chemoattractant protein-1 (MCP-1). Immunol. Today. 12:97-101.

3. Brown, K. D., S. M. Zurawski, T. R. Mosmann, and G. Zurawski. 1989. A family of small inducible proteins secreted by leukocytes are members of a new superfamily that includes leukocyte and fibroblast-derived inflammatory agents, growth factors, and indicators of various activation processes. J. Immunol. 142:679-687.

4. Oppenheim, J. J., C. O. C. Zachariae, N. Mukaida, and K. Matsushima. 1991. Properties of the novel proinflammatory supergene "intercrine" cytokine family. Annu. Rev. Immunol. 9:617-648.

5. Yoshimura, T., E. A. Robinson, S. Tanaka, E. Appella, and E. J. Leonard. 1962. Purification and amino acid analysis of two human monocyte chemoattractants produced by phytohemagglutinin-stimulated human blood mononuclear leukocytes. J. Immunol. 142:1956-1962.

6. Yoshimura, T., N. Yuhki, S. K. Moore, E. Appella, M. I. Lerman, and E. J. Leonard. 1989. Human monocyte chemoattractant protein-1 (MCP-1). Fulllength cDNA cloning, expression in mitogen-stimulated blood mononuclear leukocytes, and sequence similarity to mouse competence. FEBS (Fed. Eur. Biochem. Soc.) Lett. 244:487-493.

7. Rollins, B. J., E. D. Morrison, and C. D. Stiles. 1988. Cloning and expression of JE, a gene inducible by platelet-derived growth factor and whose product has cytokine-like properties. Proc. Natl. Acad. Sci. USA. 85:3738-3742.

8. Rollins, B. J., P. Stier, T. Ernst, and G. G. Wong. 1989. The human homo$\log$ of the JE gene encodes a monocyte secretory protein. Mol. Cell. Biol. 9:46874695 .

9. Rollins, B. J., C. C. Morton, D. H. Ledbetter, R. L. Eddy, Jr., and T. B. Shows. 1991. Assignment of the human small inducible cytokine A2 gene, SCYA2 (encoding JE or MCP-1), to 17q11.2-12: evolutionary relatedness of cytokines clustered at the same locus. Genomics 10:489-492.

10. Stanley, E. R. 1985. The macrophage colony-stimulating factor, CSF-1. Methods Enzymol. 116:564-587.

11. Horiguchi, J., E. Sariban, and D. Kufe. 1988. Transcriptional and posttranscriptional regulation of CSF-1 gene expression in human monocytes. $\mathrm{Mol}$. Cell. Biol. 8:3951-3954.

12. Introna, M., R. C. Bast Jr., C. S. Tannenbaum, T. A. Hamilton, and D. O Adams. 1987. The effect of LPS on expression of the early "competence" genes $\mathrm{JE}$ and $\mathrm{KC}$ in murine peritoneal macrophages. J. Immunol. 138:3891-3896.

13. Ernst, T. J., A. R. Ritchie, G. D. Demetri, and J. D. Griffin. 1989. Regulation of granulocyte- and monocyte-colony stimulating factor mRNA levels in human blood monocytes is mediated primarily at a post-transcriptional level. $J$. Biol. Chem. 254:5700-5703.

14. Sherman, M. L., B. L. Weber, R. Datta, and D. W. Kufe. 1990. Transcriptional and posttranscriptional regulation of macrophage-specific colony stimulating factor gene expression by tumor necrosis factor: involvement of arachidonic acid metabolites. J. Clin. Invest. 85:442-447.

15. Strieter, R. M., R. Wiggins, S. H. Phan, B. L. Wharram, H. J. Showell, D. G. Remick, S. W. Chensue, and S. L. Kunkel. 1989. Monocyte chemotactic protein gene expression by cytokine-treated human fibroblasts and endothelial cells. Biochem. Biophys. Res. Commun. 162:694-700.
16. Rollins, B. J., T. Yoshimura, E. J. Leonard, and J. S. Pober. 1990. Cytokine-activated human endothelial cells synthesize and secrete a monocyte chemoattractant, MCP-1/JE. Am. J. Pathol. 136:1229-1233.

17. Standiford, T. J., S. L. Kunkel, S. H. Phan, B. J. Rollins, and R. M. Strieter. 1991. Alveolar macrophage-derived cytokines induce monocyte chemoattractant protein-1 expression from human pulmonary type II-like epithelial cells. J. Biol. Chem. 266:9912-9918.

18. Shyy, Y-J., Y-S. Li, and P. E. Kolattukudy. 1990. Structure of human monocyte chemotactic protein gene and its regulation by TPA. Biochem. Biophys. Res. Commun. 169:346-351.

19. Kawahara, R. S., Z-W. Deng, and T. F. Deuel. 1991. Glucocorticoids inhibit the transcriptional induction of JE, a platelet-derived growth factor-inducible gene. J. Biol. Chem. 266:13261-13266.

20. Rovin, B. H., T. Yoshiumura, and L. Tan. 1992. Cytokine-induced production of monocyte chemoattractant protein-1 by cultured human mesangial cells. J. Immunol. 148:2148-2153.

21. Zoja, C., J. Ming, S. Bettoni, M. Sironi, D. Renzi, F. Chiaffarino, H. E. Abboud, J. VanDamme, A. Mantovani, G. Remuzzi, et al. 1991. Interleukin-1B and tumor necrosis factor-A induce gene expression and production of leukocyte chemotactic factors, colony-stimulating factors, and interleukin-6 in human mesangial cells. Am. J. Pathol. 138:991-1003.

22. Hora, K., J. A. Satriano, A. Santiago, T. Mori, E. R. Stanley, Z. Shan, and D. Schlondorff. 1992. Receptors for IgG complexes activate synthesis of monocyte chemoattractant peptide 1 and colony-stimulating factor 1. Proc. Natl. Acad. Sci. USA. 89:1745-1749.

23. Schlondorff, D. 1987. The glomerular mesangial cell: an expanding role for a specialized pericyte. FASEB J. 1:272-281

24. Schlondorff, D., and T. Mori. 1990. Contributions of mesangial cells to glomerular immune functions. Klin. Wochensch. 68:1138-1144.

25. Stahl, R., M. Disser, K. Hora, and D. Schlondorff. 1992. Increased expression of monocyte chemoattractant protein in glomeruli from rats with anti Thy-1 glomerulonephritis. Am. Soc. Nephrol. 3:616a. (Abstr.)

26. Satriano, J. A., K. Hora, Z. Shan, E. R. Stanley, T. Mori, and D. Schlondorff. 1993. Regulation of monocyte chemoattractant peptide (MCP-1) and macrophage colony stimulating factor (CSF-1) by interferon-y, tumor necrosis factora, IgG aggregates and cAMP in mouse mesangial cells (MC). J. Immunol. 150:1971-1978.

27. Schreck, R., P. Rieber, and P. A. Baeuerle. 1991. Reactive oxygen intermediates as apparently widely used messengers in the activation of the NF-B transcription factor and HIV-1. EMBO (Eur. Miol. Biol. Organ.) J. 10:22472258.

28. Toledano, M. B., and W. J. Leonard. 1991. Modulation of transcription factor NF-кB binding activity by oxidation-reduction in vitro. Proc. Natl. Acad. Sci. USA. 88:4328-4332.

29. Schreck, R., and P. A. Baeuerle. 1991. A role for oxygen radicals as second messengers. Trends Cell Biol. 1:39-42.

30. Meier, B., A. R. Cross, J. T. Hancock, F. J. Kaup, and T. G. Jones. 1991. Identification of a superoxide-generating NADPH oxidase system in human fibroblasts. Biochem. J. 275:241-245.

31. Radeke, H. H., A. R. Crossi, J. T. Hancock, O. T. Jones, M. Nakamura, V. Kaever, and K. Resch. 1991. Functional expression of NAPDH oxidase components (alpha- and beta-subunits of cytochrome $b_{558}$ and 45-kD flavoprotein) by intrinsic human glomerular mesangial cells. J. Biol. Chem. 266:21025-21029.

32. Radeke, H. H., B. Meier, N. Topley, J. Floge, G. G. Habermehl, and K Resch. 1990. Interleukin 1-alpha and tumor necrosis factor-alpha induce oxygen radical production in mesangial cells. Kidney Int. 37:767-775.

33. Baud, L., J. Hagege, J. Sraer, E. Rondeau, J. Perez, and R. Ardaillou. 1983. Reactive oxygen production by cultured rat glomerular mesangial cells during phagocytosis is associated with stimulation of lipoxygenase activity. $J$. Exp. Med. 158:1836-1852.

34. Sedor, J. R., S. W. Carey, and S. N. Emancipator. 1987. Immune complexes bind to cultured rat glomerular mesangial cells to stimulate superoxide release: evidence for an Fc receptor. J. Immunol. 138:3751-3757.

35. Ladner, M. B., G. A. Martin, J. A. Noble, V. P. Wittman, P. J. Shadle, M. K. Warren, M. McGrogan, and E. R. Stanley. 1988. cDNA cloning and expression of murine CSF-1 from L929 cells. Proc. Natl. Acad. Sci. USA. 85:67066710.

36. Wolf, G., U. Haberstroh, and E. G. Neilson. 1992. Angiotensin II stimulates the proliferation and biosynthesis of type I collagen in cultured murine mesangial cells. Am. J. Pathol. 140:95-107.

37. Pick, E. A., and D. Mizel. 1981. Rapid microassays for the measurement of superoxide and hydrogen peroxide production by macrophages in culture using an automatic enzyme immunoassay reader. J. Immunol. Methods. 46:211226.

38. Chomczynski, P., and N. Sacchi. 1987. Single-step method of RNA isolation by acid guanidinium thiocyanate-phenol-chloroform extraction. Anal. Biochem. 162:156-159.

39. Thomas, P. S. 1980. Hybridization of denatured RNA and small DNA fragments transferred to nitrocellulose. Proc. Natl. Acad. Sci. USA. 77:52015205. 
40. Feinberg, A. P., and B. Vogelstein. 1983. A technique for radiolabeling DNA restriction endonuclease fragments to high specific activity. Anal. Biochem. 132:6-13.

41. Ausubel, F. M., et al. 1988. Current Protocols in Molecular Biology, Volume 1. Greene Publishing Assoc. \& Wiley-Interscience, New York.

42. Wasil, M., B. Halliwell, M. Grootveld, C. P. Moorhouse, C. S. Hutchinson, and H. Baum. 1987. The specificity of thiourea, dimethylthiourea and dimethyl sulphoxide as scavengers of hydroxyl radicals. Biochem. J. 243:867-870.

43. Meister, A. 1988. Glutathione. In The liver: Biology and pathobiology. J.

M. Arias, W. B. Jacoby, H. Popper, D. Schachter, and D. A. Shafritz, editors. Raven Press, New York. 401-417.

44. Staal, F. J. T., M. Roederer, and L. A. Herzenberg. 1990. Intracellular thiols regulate activation of nuclear factor $\mathrm{KB}$ and transcription of human immunodeficiency virus. Proc. Natl. Acad. Sci. USA. 87:9943-9947.

45. Tan, D., J. A. Satriano, M. Shuldiner, Z. Shan, and D. Schlondorff. 1992. Cellular redox state influences mRNA for collagen I in mesangial cells (MC): potential implications for diabetic glomerulopathy. J. Am. Soc. Nephrol. 3:767a. (Abstr.)

46. Suzuki, Y., W. Wang, T. H. Vu, and T. A. Raffin. 1992. Effect of NADPH oxidase inhibition on endothelial cell Elam-1 mRNA expression. Biochem. Biophys. Res. Commun. 184:1339-1343.

47. Abate, C., L. Patel, F. J. Rauscher, III, and T. Curran. 1990. Redox regulation of Fos and Jun DNA-binding activity in vitor. Science (Wash. DC). 249:1157-1161.

48. Knauss, T. C., P. Mene, S. A. Ricanati, M. Kester, G. R. Dubyak, S. N.
Emancipator, and J. R. Sedor. 1989. Immune complex activation of rat glomerular mesangial cells: dependence on the Fc region of antibody. Am. J. Physiol. 257:F478-F485.

49. Meichle, A., S. Schutze, G. Hensel, D. Brunsing, and M. Kronke. 1990. Protein kinase $\mathrm{C}$-independent activation of nuclear factor $\kappa \mathrm{B}$ by tumor necrosis factor. J. Biol. Chem. 255:8339-8343.

50. Shaw, G., and R. Kamen. 1986. A conserved AU sequence from the 3 untranslated region of GM-CSF mRNA mediates selective mRNA degradation. Cell. 46:659-667.

51. Baeuerle, P. A. 1991. The inducible transcription activator NF- $\kappa$ B: regulation by distinct protein subunits. Biochim. Biophys. Acta. 1072:63-80.

52. Harrington, M. A., H. J. Edenberg, S. Saxman, L. M. Pedigo, R. Daub, and H. E. Broxmeyer. 1991. Cloning and characterization of the murine promoter for the colony-stimulating factor-1-encoding gene. Gene. 102:165-170.

53. Safirstein, R., J. Megyesi, S. J. Saggi, P. M. Price, M. Poon, B. J. Rollins, and M. B. Taubman. 1991. Expression of cytokine-like genes JE and KC is increased during renal ischemia. Am. J. Physiol. 261:F1095-F1101.

54. Oberle, G. P., J. Niemeyer, F. Thaiss, W. Schoeppe, and R. A. K. Stahl. 1992. Increased oxygen radical and eicosanoid formation in immune-mediated mesangial cell injury. Kidney Int. 42:69-74.

55. Adler, S., P. J. Baker, R. J. Johnson, R. F. Ochi, P. Pritzi, and W. G. Couser. 1986. Complement membrane attack complex (C5b-9) stimulates production of reactive oxygen species by rat mesangial cells. J. Clin. Invest. 77:762767 